\title{
A Study on Effects of Time Pressure Perceived by Users of Airport Duty-free Shop on Impulsive Purchasing Behavior and repurchase Intention
}

\author{
Kang-Yeol Lee ${ }^{1}$, Yu-Jin, Choi ${ }^{2}$, Jin-Woo Park ${ }^{3}$ \\ ${ }^{1}$ Senoir Manager, Terminal 2 Interior Construct Team, Incheon International Airport, South Korea \\ ${ }^{2}$ Assistant Researcher, Airport Research Institute, Incheon International Airport Corporation, South Korea \\ ${ }^{3}$ Associate Professor, School of Business, Korea Aerospace University, South Korea \\ Correspondence: Jin-Woo Park, Associate Professor, School of Business, Korea Aerospace University, 76 \\ Hanggongdaehak-ro, Deokyang-gu, Deokyang-gu, Goyang-si, Gyeonggi-do, 421-791, South Korea.
}

Received: October 31, 2017

Accepted: November 22, 2017

Online Published: December 1, 2017

doi:10.5539/ibr.v11n1p59

URL: https://doi.org/10.5539/ibr.v11n1p59

\begin{abstract}
The purpose of this research is to analyze the effects of time pressure perceived by users of the airport duty-free shop on impulsive purchasing behavior, satisfaction, and repurchase intention. For the purpose, we have carried out a questionnaire survey with users of the duty-free shop at the Incheon International Airport who are waiting to get on-board after purchasing duty-free goods at the airport duty-free shop as target. A total of 203 questionnaires were analyzed using structural equation modeling. As a result of the analysis, time pressure turned out to have a significant effect on impulsive purchasing behavior and repurchase intention, and satisfaction turned out to have a positive effect on repurchase intention. On the other hand, the effect of impulsive purchasing behavior on satisfaction and repurchase intention turned out to be insignificant statistically.
\end{abstract}

Keywords: airport duty-free shop, time pressure, impulsive purchasing behavior, satisfaction, repurchase intention

\section{Introduction}

At the Incheon International Airport (IIA), more than $60 \%$ of its total sales come from non-aviation revenues, of which the greatest portion of the sales is occupied by the airport duty-free shop. This can be attributed to the growing trend of Koreans and foreign tourists from China and Japan which constitutes an $85 \%$ of the sales of the duty-free shop with high propensity for consumption. For the reason described above, the duty-free shop of the IIA is expected to maintain continuous growth at $7 \%$ of average annual growth until 2020 based on the future increase in aviation demand. Thanks to this growth, the duty-free shop of the IIA is already operating a number of promotion projects for sales increase such as discount, coupon, and membership system. But due to short shopping time in comparison to city-based duty-free shops, there is a need for concrete studies on time pressure which is an important factor for sales increase in the future.

Customers who use the airport duty-free shop tend to feel considerable time pressure for shopping due to tight aircraft boarding time. Therefore, it is very important to grasp the effect of time pressure perceived by users of the duty-free shop due to limited shopping time and to analyze the effect it has on satisfaction and repurchase intention. Accordingly, an attempt is made in this research to grasp paths of impulsive purchasing behavior and repurchase intention caused by time pressure and examine inter-relations among these factors in an effort to derive implications that can be applied in establishing an operation strategy of the airport duty-free shop.

\section{Theoretical Background}

\subsection{Time Pressure and Impulsive Purchasing Behavior}

Howard \& Sheth (1969) have defined time pressure as the state in which consumers feel shortage of time while involved in purchasing and consuming behavior from the perspective of consumer behavior. Solomon (2012) has defined it as a subjective psychological state of consumers who feel time poverty. Umesh et al. (1989) have discovered that consumers who are sensitive about time purchase a large quantity of goods at one time to reduce the time they stay at a store and the number of shopping time. The easier is access of consumers to the location 
of a store, its facilities and its form, urgency of consumers toward time who are being pressed for time is reduced and quality of their shopping experience is increased (Herrington, 1995). Because of this, the degree of time pressure appears differently based on individual and situational characteristics (Rastegary \& Landy, 1993). In this research, time pressure can be understood as a psychological state in which users of the airport duty-free shop feel shortage of time available to them for shopping. Dhar \& Nowlis (1999) have identified appearance of salient characteristics in consumers under time pressure, and this is because consumers use more heuristic under situations of time constraints to simplify their cognitive task. For this reason, when there are time restraints, there is a good possibility that consumers would purchase goods impulsively as there is little likelihood to search for information and process them (Brehm, 1966).

Impulsive purchasing refers to the behavior of immediate purchasing in a state where purchasing was not intended before consumers enter into a sales outlet (Rook \& Fisher, 1995). It is a shopping action that appears immediately in response to a particular situation and atmosphere and which is hard to control for consumers. Vohs \& Faber (2007) claimed that the phenomenon of impulsive purchasing occurs more frequently when consumers react to various factors emotionally in a shopping environment. Impulsive purchasing includes both unplanned purchasing and unintended purchasing before consumers visit a sales outlet (Faber \& O'Guinn, 1992; Stern, 1962). As characteristics of impulsive purchasing, it occurs often when subsequent result after purchasing is not considered, and the required time between the time when consumers find an item to purchase and the time when they actually purchase is short (Rook \& Fisher, 1995). In other words, consumers make an instant decision due to a sudden desire to possess a commodity (Lee \& Kacen, 2008). In this research, impulsive purchasing can be defined as purchasing behavior that occurs with no regard to a purchasing plan due to a shopping desire on the part of consumers which was stimulated by a shopping environment of the airport duty-free shop (Hodge, 2004). Hausman (2000) claimed that impulsive purchasing is basically not an action intended to achieve a particular objective. Rather, it is an action that can evoke repurchase intention and satisfaction by itself since it engenders hedonic fulfillment. Gardner \& Rook (1988) have stated that, in impulsive purchasing, there co-exist contrasting emotions since consumers are satisfied after impulsive purchasing while they feel certain sense of guilt at the same time. According to Xiao (2012), in the case of impulsive purchasing too, satisfaction with the result of one's decision can be great even though it is not a rational purchase.

\subsection{Satisfaction and Repurchase Intention}

Customer satisfaction, an overall evaluation that is based on accumulated experience of repeated purchasing, has attracted steady attention as a major means of loyalty management in marketing (Szymanski \& Henard, 2001). That is, as a variable that plays an important role in enabling customer maintenance and in bringing about profitability, customer satisfaction is regarded as a practical scale that is used to evaluate corporate development. In this research, it was defined as an evaluation for subjective satisfaction perceived on the goods purchased at the airport duty-free shop and the particular shopping environment. The fact that customer satisfaction is a precondition for loyalty that encompasses repurchase, service maintenance, and positive word of mouth is already verified by existing studies (Lam et al., 2004). Furthermore, it was already proved that the customers who are satisfied with a particular good or service often entertain the intention to repurchase or influence others by way of favorable communication (Kristensen et al., 1999).

Repurchase intention not only has a great effect on corporate record, it often serves as an important resource for competitive advantage. Oliver (2014) have noted that it is an intention to use the service provided again on the part of a purchaser based on past experience. According to Biong (1993), repurchase intention is closely related to both actual repurchasing behavior and a long-term strategy for maintaining customers, and as such it is treated importantly in marketing together with customer satisfaction (Hof et al., 2000). In this research, repurchase intention signifies a personal judgment as to the possibility of repurchase from the airport duty-free shop that provided goods and services in the past.

\subsection{Research Model and Hypotheses}

In order to analyze the effects of time pressure within an airport duty-free shop, a model was designed and analyzed in this research on relationships among time pressure, impulsive purchasing behavior, satisfaction, and repurchase intention <Figure 1>. Research hypotheses are marked with arrows, and all hypotheses are set up as a positive entity. 


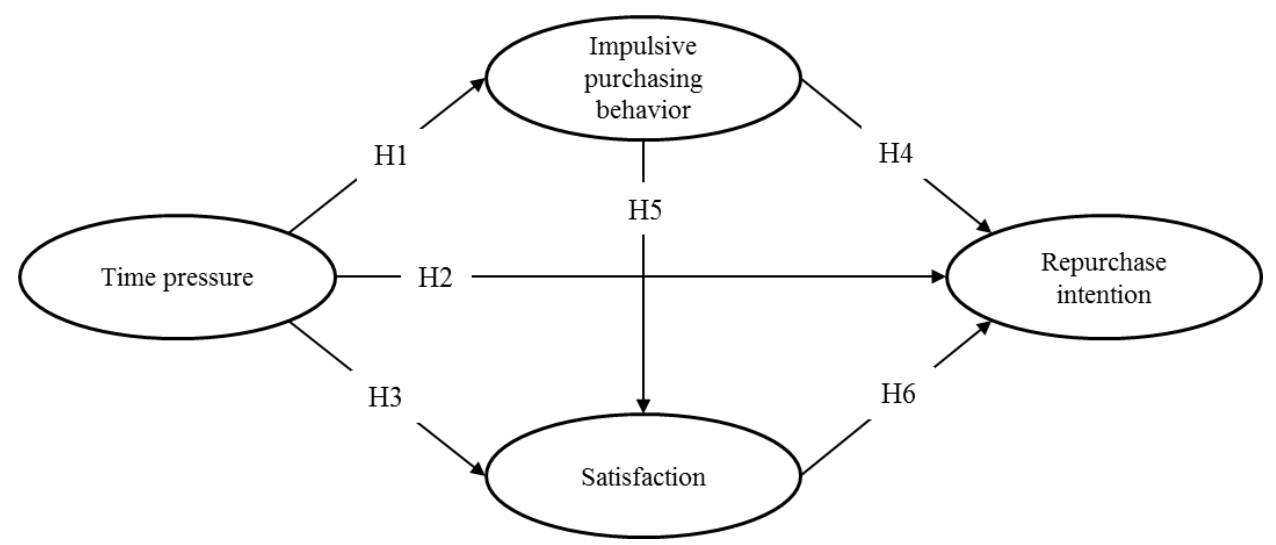

Figure 1. Conceptual model

\section{Methodology}

In order to analyze hypotheses of this research empirically, we have derived questionnaire items based on factors related to preceding studies, and carried out a pilot-test with 52 users of the duty-free shop at IIA who have completed shopping and were waiting to get on-board at the boarding lounge as target. And based on an analysis of preliminary survey results, we have drawn up the final questionnaire with modifications on the form of questionnaire construction and certain items in an effort to facilitate understanding of the respondents and enhance reliability and validity by variable. Measurement items that have been used in this research are as shown in Table 1, and each item is displayed in such a way that [Very much so (5) - Not very much so (1)] can be marked using a 5-point Likert scale <Table 1>.

Table 1. Measurement items

\begin{tabular}{|c|c|}
\hline $\begin{array}{l}\text { Time } \\
\text { pressure }\end{array}$ & $\begin{array}{l}\text { When shopping at the duty-free shop, I had to finish shopping hurriedly. } \\
\text { When shopping at the duty-free shop, I had to finish shopping under time pressure. } \\
\text { When shopping at the duty-free shop, I did not have sufficient time for shopping. } \\
\text { When shopping at the duty-free shop, I finished shopping hurriedly. }\end{array}$ \\
\hline $\begin{array}{l}\text { Impulsive } \\
\text { purchasing } \\
\text { behavior }\end{array}$ & $\begin{array}{l}\text { I did not have a plan to purchase at the airport duty-free shop, but there are goods that I } \\
\text { purchased impulsively. } \\
\text { I have goods purchased impulsively in addition to the goods I originally planned to purchase } \\
\text { at the airport duty-free shop. }\end{array}$ \\
\hline Satisfaction & $\begin{array}{l}\text { I am satisfied overall on the duty-free shopping this time. } \\
\text { I am satisfied with the duty-free goods purchased at the duty-free shop overall this time. } \\
\text { I am satisfied with my shopping at the duty-free shop this time. }\end{array}$ \\
\hline $\begin{array}{l}\text { Repurchase } \\
\text { intention }\end{array}$ & $\begin{array}{l}\text { I intend to repurchase duty-free goods at the airport duty-free shop in the future. } \\
\text { I would like to purchase again at the airport duty-free shop next time. }\end{array}$ \\
\hline \multicolumn{2}{|c|}{$*$ Note: Five-point Likert scale } \\
\hline $\begin{array}{l}\text { Sample fo } \\
\text { duty-free } \\
2011 \text { and } \\
\text { survey wa } \\
\text { questionn }\end{array}$ & $\begin{array}{l}\text { ey target was chosen from among Korean passengers who have completed shopping at the } \\
\text { f IIA that has maintained the top rank in sales among airport duty-free shops in the world since } \\
\text { vaiting to get on-board at the boarding gate after completing their shopping. The questionnaire } \\
\text { ied out for about } 2 \text { weeks from June } 15 \text { to June } 23,2013 \text {. A total of } 253 \text { copies of the } \\
\text { re distributed and } 211 \text { copies were recovered. But for final analysis, only } 203 \text { copies were used } \\
\text { that contained insincere answers or unanswered items. General characteristics of the sample are }\end{array}$ \\
\hline
\end{tabular}


Table 2. Sample Characteristics

\begin{tabular}{|c|c|c|c|}
\hline \multicolumn{2}{|r|}{ Division } & \multirow{2}{*}{$\begin{array}{c}\text { Frequency(Persons) } \\
102\end{array}$} & \multirow{2}{*}{$\frac{\text { Ratio (\%) }}{50.2 \%}$} \\
\hline Sex & Male & & \\
\hline & Female & 101 & $49.8 \%$ \\
\hline \multirow[t]{5}{*}{ Age } & $20 \sim 29$ years old & 30 & $14.8 \%$ \\
\hline & $30 \sim 39$ years old & 72 & $35.5 \%$ \\
\hline & $40 \sim 49$ years old & 36 & $17.7 \%$ \\
\hline & $50 \sim 59$ years old & 40 & $19.7 \%$ \\
\hline & 60 years old or older & 25 & $12.3 \%$ \\
\hline \multirow[t]{9}{*}{ Shopping time } & Less than 10 minutes & 11 & $5.4 \%$ \\
\hline & $11 \sim 20$ minutes & 22 & $10.8 \%$ \\
\hline & $21 \sim 30$ minutes & 41 & $20.2 \%$ \\
\hline & $31 \sim 40$ minutes & 40 & $19.7 \%$ \\
\hline & $41 \sim 50$ minutes & 19 & $9.4 \%$ \\
\hline & $51 \sim 60$ minutes & 21 & $10.3 \%$ \\
\hline & 1 hour $\sim$ Less than 1.5 hour & 28 & $13.8 \%$ \\
\hline & 1.5 hour $\sim$ Less than 2 hours & 12 & $5.9 \%$ \\
\hline & 2 hours or longer & 9 & $4.4 \%$ \\
\hline \multirow{11}{*}{$\begin{array}{l}\text { Amount of } \\
\text { shopping }\end{array}$} & Less than 100,000 won & 47 & $23.2 \%$ \\
\hline & $110,000 \sim 150,000$ won & 14 & $6.9 \%$ \\
\hline & $160,000 \sim 200,000$ won & 24 & $11.8 \%$ \\
\hline & $210,000 \sim 250,000$ won & 18 & $8.9 \%$ \\
\hline & $260,000 \sim 300,000$ won & 23 & $11.3 \%$ \\
\hline & $310,000 \sim 350,000$ won & 17 & $8.4 \%$ \\
\hline & $360,000 \sim 400,000$ won & 13 & $6.4 \%$ \\
\hline & $410,000 \sim 450,000$ won & 9 & $4.4 \%$ \\
\hline & $460,000 \sim 500,000$ won & 12 & $5.9 \%$ \\
\hline & 510,000 won or more & 26 & $12.8 \%$ \\
\hline & Number of total valid respondents & 203 & $100.0 \%$ \\
\hline
\end{tabular}

\section{Empirical Results}

In this research, before verifying hypotheses using a structural equation model, we have carried out a reliability analysis and a validity analysis of measurement concepts. As a result of confirmatory factor analysis, values for model fit indexes turned out to be $\mathrm{x}^{\wedge} 2(38)$ of $67.661, \mathrm{p}=0.002 ; \mathrm{RMR}=0.028 ; \mathrm{GFI}=0.942$; $\mathrm{AGFI}=0.9$; $\mathrm{TLI}=$ 0.977; CFI $=0.984$. That is, model fit index for each turned out to be suitable to adoption level, suggesting that the model of this research is quite suitable to the data. Squared Multiple Correlation (SMC) values turned out to be 0.7 or above for all measurement variables, and values for standardized loadings also turned out to be 0.8 or above $\langle$ Table 3>.

Table 3. Result of Confirmatory Factor Analysis

\begin{tabular}{|c|c|c|c|c|c|}
\hline Factor & Variable & SMC & Standardized Loading & Loading & C. R. \\
\hline \multirow[t]{4}{*}{ Time pressure } & Time pressure -1 & 0.861 & 0.928 & 1.07 & 21.893 \\
\hline & Time pressure -2 & 0.905 & 0.951 & 1.118 & 23.38 \\
\hline & Time pressure -3 & 0.82 & 0.906 & 1.000 & Fix \\
\hline & Time pressure -4 & 0.788 & 0.888 & 1.036 & 19.932 \\
\hline $\begin{array}{l}\text { Impulsive } \\
\text { purchasing }\end{array}$ & $\begin{array}{l}\text { Impulsive purchasing } \\
\text { behavior }-1\end{array}$ & 0.738 & 0.859 & 1.000 & Fix \\
\hline behavior & $\begin{array}{l}\text { Impulsive purchasing } \\
\text { behavior }-2\end{array}$ & 0.832 & 0.912 & 1.093 & 6.197 \\
\hline \multirow[t]{3}{*}{ Satisfaction } & Satisfaction -1 & 0.715 & 0.845 & 1.000 & Fix \\
\hline & Satisfaction -2 & 0.875 & 0.936 & 1.107 & 17.873 \\
\hline & Satisfaction -3 & 0.832 & 0.912 & 1.096 & 17.156 \\
\hline \multirow[t]{2}{*}{$\begin{array}{l}\text { Repurchase } \\
\text { intention }\end{array}$} & $\begin{array}{l}\text { Repurchase intention } \\
-1\end{array}$ & 0.825 & 0.908 & 1.000 & Fix \\
\hline & $\begin{array}{l}\text { Repurchase intention } \\
-2\end{array}$ & 0.799 & 0.894 & 1.048 & 12.588 \\
\hline
\end{tabular}

\footnotetext{
*Note: Values in parentheses are critical ratios and all the values are significant $(\mathrm{p}<0.001)$

As a result of validity analysis using Average Variance Extracted (AVE) and construct reliability, values for most measurement item analyses turned out to be suitable to adoption level <Table 4>. Internal consistency was secured as construct reliability was 0.851 or above, and convergent validity was secured among measurement variables used in this research since AVE values also turned out to be 0.785 or above. Discriminant validity also proved to be secured since average values for each factor turned out to exceed squared value of correlation coefficients.
} 
Table 4. Results of Construct Validity Analyses (Construct Reliability, AVE)

\begin{tabular}{|c|c|c|c|c|c|c|}
\hline Variable & $\begin{array}{l}\text { Construct } \\
\text { Reliability }\end{array}$ & $\begin{array}{l}\text { Average } \\
\text { Variance } \\
\text { Extracted }\end{array}$ & Time Pressure & $\begin{array}{c}\text { Impulsive } \\
\text { Purchasing }\end{array}$ & Satisfaction & $\begin{array}{l}\text { Repurchase } \\
\text { Intention }\end{array}$ \\
\hline Time Pressure & 0.945 & 0.844 & 1 & & & \\
\hline $\begin{array}{l}\text { Impulsive } \\
\text { Purchasing }\end{array}$ & 0.851 & 0.785 & 0.102 & 1 & & \\
\hline Satisfaction & 0.945 & 0.807 & 0.002 & 0.000 & 1 & \\
\hline $\begin{array}{l}\text { Repurchase } \\
\text { Intention }\end{array}$ & 0.920 & 0.812 & 0.045 & 0.021 & 0.350 & 1 \\
\hline
\end{tabular}

After completing a confirmatory factor analysis, verification was carried out for the structural equation model based on covariance matrix among factors using maximum likelihood method. As a result of verification, values for model fit indexes turned out to be $\chi^{2}=44.573, \mathrm{DF}=37, \mathrm{CMIN} / \mathrm{DF}=1.205, \mathrm{RMR}=0.028, \mathrm{GFI}=0.963$, AGFI $=0.934, \mathrm{NFI}=0.977, \mathrm{RFI}=0.966, \mathrm{IFI}=0.996, \mathrm{TLI}=0.994, \mathrm{CFI}=0.996, \mathrm{RMSEA}=0.032$. As these values were above adoption level, the model used in this research was verified to be suitable. Verification results of the hypotheses are as shown in $\langle$ Table 5>.

Table 5. Verification Results of Hypotheses

\begin{tabular}{cccccc}
\hline Hypothesis & Path & Estimate & C. R. & S. E. & Result \\
\hline H1 & Time pressure $\rightarrow$ Impulsive purchasing behavior & $0.311^{* * *}$ & 3.863 & 0.082 & Supported \\
H2 & Time pressure $\rightarrow$ Repurchase intention & $0.16^{*}$ & 2.407 & 0.053 & Supported \\
H3 & Time pressure $\rightarrow$ Satisfaction & 0.049 & 0.624 & 0.06 & Rejected \\
H4 & Impulsive purchasing behavior $\rightarrow$ Repurchase & 0.089 & 1.292 & 0.055 & Rejected \\
H5 & intention & -0.002 & -0.027 & 0.061 & Rejected \\
H6 & Satisfaction $\rightarrow$ Repurchase intention & $0.583^{* * *}$ & 8.221 & 0.075 & Supported \\
\hline
\end{tabular}

Note: $* \mathrm{p}<0.05, * * * \mathrm{p}<0.01$

Regarding the effect of time pressure on impulsive purchasing behavior, standardized estimate value turned out to be 0.311 , and C.R value turned out to be 3.863. Regarding the effect of time pressure on repurchase intention, standardized estimate value turned out to be 0.016 , and C.R value turned out to be 2.407 . From this, it is clear that hypotheses $\mathrm{H} 1$ and $\mathrm{H} 2$ are supported. When information that boarding time is imminent is given, it evokes a strong temptation in the minds of passengers to purchase goods as their attentiveness is raised. This discovery serves as an empirical evidence for the elaboration likelihood model of Cacioppo \& Petty (1980) who claimed that, when information processing ability of consumers is restrained by time pressure, tendency to purchase goods based on price, brand or explanations of a sales personnel is heightened. On the other hand, the effect of time pressure on satisfaction turned out to be not significant statistically. This result is identical with that of Lee's analysis (2010). When time pressure is high, information and time that are necessary for purchase decision is not sufficient, causing confusion in decision making. This explains post-purchase regret and dissatisfaction.

The effect of impulsive purchasing behavior on repurchase intention turned out to be not significant statistically. On the other hand, regarding the relationship between satisfaction and repurchase intention, standardized estimate value turned out to be 0.583 , and C.R value turned out to be 8.221 , both of which are statistically significant. It is not that users of the airport duty-free shop feel satisfaction through time pressure and impulsive purchasing. Rather, it is that, when their expectation for the airport duty-free shop is exceeded, they feel more satisfaction which leads to repurchasing.

\section{Conclusion}

This research has academic significance in that it analyzes the relationship between time pressure that is important in establishing an operation strategy of the airport duty-free shop, which is characterized by short and limited shopping time, and impulsive purchasing behavior. This research has confirmed that time pressure is an antecedent variable for impulsive purchasing behavior, satisfaction, and repurchase intention as it functions as a stimulation factor, and contributed to broadening of the research by verifying inter-relationships among them. As a result of this research, time pressure turned out to have positive effects on impulsive purchasing and repurchase intention. Based on this kind of result, there is a need to apply time pressure marketing that is mainly employed in home shopping to the airport duty-free shop that has similar conditions. As is well known, obsession on decision making is one of the basic characteristics of Korean people due to hot temper. If time pressure marketing is applied, the possibility that it could lead to actual purchasing would be enhanced that much. Therefore, there is a need for IIA to utilize this stimulation factor more actively in its effort to come up with a new strategy 
Despite these implications, however, this research has the following limitations to be overcome before we can propose a direction for future research. First, the sample of this research was limited to Korean users which preempted consideration of overall distribution of users that includes foreigners. Hence, in the future, comprehensive research that includes foreigners who use the airport duty-free shop would be needed. Second, in this research, the concept of time pressure perceived by users of the airport duty-free shop is defined as one that is based on one's subjective judgment with no regard to actual shopping time of users who feel the time pressure or the amount of shopping involved. Hence, in the future, empirical research would be needed that takes time pressure, shopping time, and amount of shopping into consideration. Also, as external factors that induce impulsive purchasing, not only time pressure but diverse other variables should also be taken into consideration. If these limitations can be complemented by overall grasp of actual situations in conducting a questionnaire survey, the result of present research can be utilized more usefully including theoretical extension.

\section{Acknowledgments}

Authors of this research would like to express heartfelt thanks to authorities at Incheon International Airport for their assistance in enabling us to conduct a questionnaire survey with users of the airport duty-free shop at the boarding gate of the airport as target.

\section{References}

Biong, H. (1993). Satisfaction and Loyalty to Suppliers within the Grocery Trade. European Journal of Marketing, 27(7), 21-38. https://doi.org/10.1108/03090569310040334

Brehm, J. W. (1966). A theory of psychological reactance. New York: Academic Press.

Cacioppo, J. T., \& Petty, R. E. (1984). The elaboration likelihood model of persuasion. Advances in Consumer Research, 11(1), 673-675.

Dhar, R., \& Nowlis, S. M. (1999). The effect of time pressure on consumer choice deferral. Journal of Consumer Research, 25(4), 369-384. https://doi.org/10.1086/209545

Duncan, H. J., \& Capella, L. M. (1995). Shopper reactions to perceived time pressure. International Journal of Retail \& Distribution Management, 23(12), 13-20. https://doi.org/10.1108/09590559510103963

Faber, R. J., \& O'guinn, T. C. (1992). A clinical screener for compulsive buying. Journal of Consumer Research, 19(3), 459-469. https://doi.org/10.1086/209315

Gardner, M. P., \& Rook, D. W. (1988). Effects of impulse purchases on consumers' affective states. Advances in Consumer Research, 15(1), 127-130. Retrieved from http://www.acrwebsite.org/search/view-conference-proceedings.aspx?Id=6803

Hausman, A. (2000). A multi-method investigation of consumer motivations in impulse buying behavior. Journal of Consumer Marketing, 17(5), 403-426. https://doi.org/10.1108/07363760010341045

Hodge, R. (2004). Factors influencing impulse buying during an online purchase transaction. Master thesis, University of Waterloo, CA. http://hdl.handle.net/10012/912

Hof, R. D., McWilliams, G., \& Saveri, G. (1998). The click here economy. Business Week, 22(6583), 122.

Howard, J. A., \& Sheth, J. N. (1969). The theory of buyer behavior. New York: Wiley

Kristensen, K., Martensen, A., \& Gronholdt, L. (1999). Measuring the impact of buying behaviour on customer satisfaction. Total Quality Management, 10(4-5), 602-614. https://doi.org/10.1080/0954412997587

Lam, S. Y., Shankar V., \& Erramilli M. K. et al. (2004). Customer value, satisfaction, loyalty, and switching costs: An illustration from a business-to-business service context. Journal of the Academy of Marketing Science, 32(3), 293-311. https://doi.org/10.1177/0092070304263330

Lee, J. A., \& Kacen, J. J. (2008). Cultural influences on consumer satisfaction with impulse and planned purchase decisions. Journal of Business Research, 61(3), 265-272. https://doi.org/10.1016/j.jbusres.2007.06.006

Lee, Y. I. (2010). The Effect on Behavior Intention of Post Purchase to the Cognitive and Emotional Response Under Time Pressure. Journal of Commodity Science and Technology, 28(3), 21-30.

Oliver, R. L. (2010). Satisfaction: A behavioral perspective on the consumer. New York: M.E. Sharpe.

Rastegary, H., \& Landy, F. J. (1993). The interactions among time urgency, uncertainty, and time pressure. Time pressure and stress in human judgment and decision making, New York: Plenum Press, 217-239. https://doi.org/10.1007/978-1-4757-6846-6_15 
Rook, D. W., \& Fisher, R. J. (1995). Normative influences on impulsive buying behavior. Journal of Consumer Research, 22(3), 305-313. https://doi.org/10.1086/209452

Solomon, M., Russell-Bennett, R., \& Previte, J. (2012). Consumer Behaviour, Buying, Having, Being.

Stern, H. (1962). The significance of impulse buying today. The Journal of Marketing, 26(2), 59-62. https://doi.org/ 10.2307/1248439

Szymanski, D. M., \& Henard, D. H. (2001). Customer satisfaction: A meta-analysis of the empirical evidence. Journal of the academy of marketing science, 29(1), 16-35. https://doi.org/10.1177/009207030102900102

Umesh, U. N., Pettit, K. L., \& Bozman, C. S. (1989). Shopping model of the time - sensitive consumer. Decision Sciences, 20(4), 715-729.

http://search.proquest.com.ssl.access.yonsei.ac.kr:8080/docview/198109670?accountid=15179

Vohs, K. D., \& Faber, R. J. (2007). Spent resources: Self-regulatory resource availability affects impulse buying. Journal of consumer research, 33(4), 537-547. https://doi.org/10.1086/510228

Xiao, X. (2012) The Influence of Consumer's Intrinsic Motivation and External Stimulus on the Impulse Buying, Satisfaction, Repurchase Intention and Word of Mouth. (Unpublished Master thesis). Tongmyong Uni versity, KR.

\section{Copyrights}

Copyright for this article is retained by the author(s), with first publication rights granted to the journal.

This is an open-access article distributed under the terms and conditions of the Creative Commons Attribution license (http://creativecommons.org/licenses/by/4.0/). 